WHOI $-81-46$

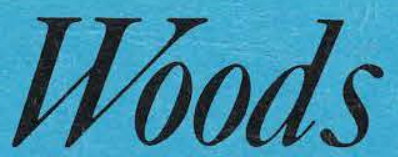

Hole

Copy 2

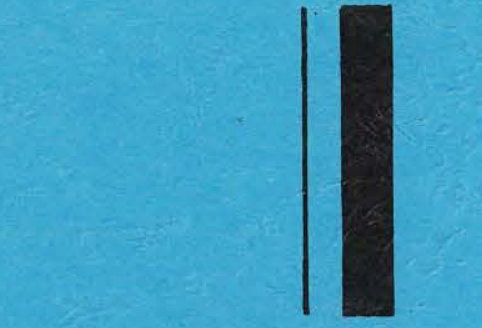

Oceanographic

Institution

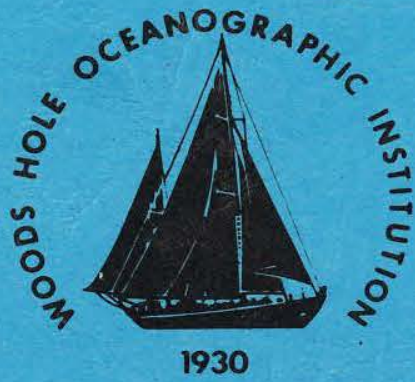

GEORGES BANK: AN ANNOTATED BIBLIOGRAPHY

OF ATLASES, INVENTORIES AND MAP SERIES

by

Richard L. Price

Marine Policy Program

May 1981

TECHNICAL REPORT

Prepared by the Marine Policy and Ocean Monagement Progrom and the Coastal Research Center with funds from the Pew Memorial Trust, the Melzon Foundation and the Department of Commerce, NOAA Office of Sea Grant under Grant NA $80 A A-D-00077$.

IVOODS HOLE, MASSACHUSETTS 02543 


$$
\text { WHOI }-81-46
$$

\title{
GEORGES BANK: AN ANNOTATED BIBLIOGRAPHY \\ OF ATLASES, INVENTORIES AND MAP SERIES
}

by

Richard L. Price

Marine Policy Program

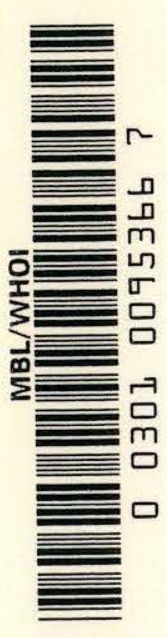

\author{
WOODS HOLE OCEANOGRAPHIC INSTITUTION
Woods Hole, Massachusetts 02543
}

A report to the Georges Bank Study Committee of the Coastal Research Center, Woods Hole Oceanographic Institution.

\section{May 1981}

\section{TECHNICAL REPORT}

Prepared by the Marine Policy and Ocean Management Program and the Coastal Research Center with funds from the Pew Memorial Trust, the Mellon Foundation and the Department of Commerce, NOAA Office of Sea Grant under Grant \#NA 80AA-D-00077.

Reproduction in whole or in part is permitted for any purpose of the United States Government. This Report should be cited as: Woods Hole Oceanog. Inst. Tech. Rept. WHOI-81-46.

Approved for Distribution:

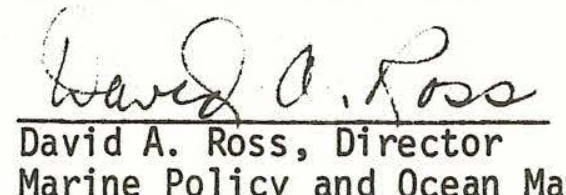

Marine Policy and Ocean Management

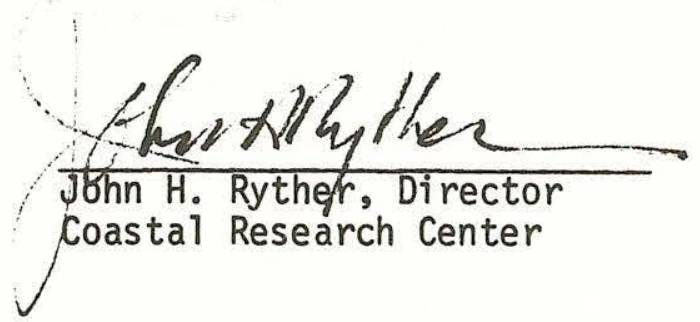




\begin{abstract}
The bibliography reviews inventory-like studies of the Georges Bank region and presents information on the scope of the work, topics treated, geographic area of concern, and audience. The primary purpose was to evaluate the nature and type of maps used in the works reviewed so the notations include the number of maps, their formats and scales, cartographic quality and base map content.
\end{abstract}


Table of Contents

Introduction $\ldots \ldots \ldots \ldots \ldots \ldots \ldots \ldots \ldots \ldots \ldots \ldots \ldots \ldots$ Methodology $\ldots \ldots \ldots \ldots \ldots \ldots \ldots \ldots \ldots \ldots \ldots \ldots \ldots \ldots \ldots \ldots \ldots \ldots \ldots \ldots$ Annotated Bibliography $\ldots \ldots \ldots \ldots \ldots \ldots \ldots \ldots \ldots \ldots \ldots$ 1. General Surveys $\ldots \ldots \ldots \ldots \ldots \ldots \ldots \ldots \ldots \ldots \ldots \ldots$

2. Fisheries and Petroleum .........................

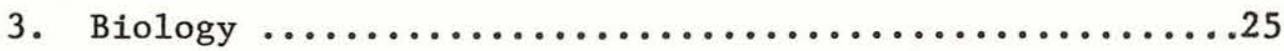

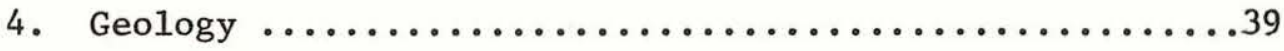

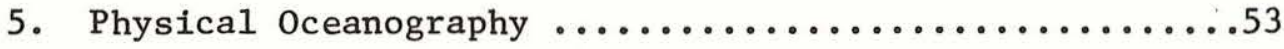

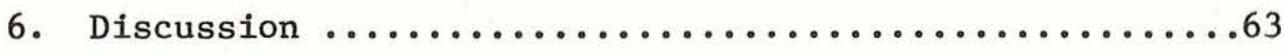

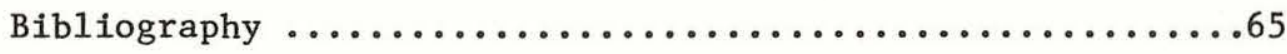




\section{Introduction}

The purpose of this report is to alert planners and prospective authors of a comprehensive WHOI sponsored book on Georges Bank to the existence of atlases and inventories which deal with the same region. A large number of such studies has been produced beginning primarily with folio 1 of the American Geographical Society's Serial Atlas of the Marine Environment (Pyle, 1962) and culminating in a variety of papers and reports related to oil exploration on Georges Bank. The main focus of the report is on the type and quality of the maps and graphics used in the studies reviewed and on the subjects treated.

Methodology

The initial purpose of this report was to review studies that were clearly "Atlases"1 of Georges Bank as, for example, the URI analysis of Fishing and Petroleum Interaction on Georges Bank, Vo1. 1 (01sen \& Saila, 1976), or the American Geographical Society's Serial Atlas of the Marine Environment (various authors). In the course of the review it became clear that other broad inventories of the region, though not strictly atlases, should also be included. These include the TRIGOM studies (1974 \& 1976), Shell 0il's survey of The Fish and Wildlife Resources of the Georges Bank

1 Defined simply as a bound collection of maps, charts, tables and graphs that systematically illustrate a subject. 


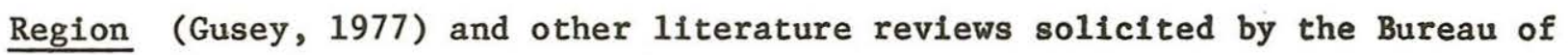
Land Management for use in the ocs leasing process (for example, Center for Natural Areas, 1977 and Roberts, et a1., 1979).

The criteria finally adopted were designed to eliminate local studies, studies of individual species distributions, and analyses of single topics in favor of broader surveys. The reports and publications reviewed, therefore, shared the following characteristics:

1) The document is concerned with portraying the spatial characteristics of the Georges Bank or adjacent environment or of the flora and fauna which occupy it;

2) The study is an inventory of more than one characteristic of the region and concerns more than simply a small portion of it;

3) Maps and other graphics are used to present the data.

Using these parameters, papers on single species were eliminated as were articles on sand waves, for example, while broader studies of decapod crustacea distributions and general geologic hazards were included. Using these criteria a study of surface water temperatures in the region (Pyle, 1962) should, perhaps, have been excluded as too narrow a topic. On the other hand, this particular study appeared as one of several monographs on the region and in the aggregate these monographs constitute a survey of water temperature and other physical and biological characteristics, so it was included. Ultimately, many arbitrary decisions had to be made and many studies were left out, studies it might be argued, which should have been included. No pretense is made that this report constitutes a complete review of the literature on Georges Bank although it is fairly complete so far as the atlas-1ike literature is concerned. 
The annotated bibliography which follows is divided by subject into five types of studies: 1) General Surveys; 2) Fisheries and Petroleum; 3) Biology; 4) Geology; and, 5) Physical Oceanography. The annotations are schematically organized so the reader can review each citation systematically as desired. The title, author and sponsoring agencies are identified, publication data are presented, and the geographic area of concern is noted, the audience is identified and the general subject matter is listed. The number, scale and format of maps is then shown with notes indicating the type of base information found on the maps and the overall quality of the maps. Finally, additional comments are included as appropriate.

The format of the annotated bibliography is as follows:

\section{1) Title}

2) Author

3) Sponsoring agency

4) Publisher (if different from sponsor)

5) Publication data

6) Geographic area of concern

7) Purpose of project

8) Audience

9) Subject matter

10) Number of maps, scales and format

11) Base information and cartographic quality

12) Other comments 
(1) GENERAL SURVEYS 
1) A SOCIO-ECONOMIC AND ENVIRONMENTAL INVENTORY OF THE NORTH ATLANTIC REGIONSANDY HOOK TO BAY OF FUNDY.

2) TRIGOM (The Research Institute of the Gulf of Maine)

3) Bureau of Land Management, Marine Minerals Division

4)

5) Contract 08550-CT3-8, November 1974 ( $4900 \mathrm{pp}$. in 3 volumes)

6) From Hudson Canyon along the 200 meter isobath to the Canadian border and shoreward to the limit of salt intrusion; including 38 counties for the socio-economic data

7) Primary objectives:

- to develop a comprehensive inventory of marine environmental data for the coastal zone and adjacent waters of the outer continental shelf

- to conduct a study of the socio-economic factors operating in the region

- to compile and synthesize the above for use in impact assessments relating to the development of offshore energy resources

- to define gaps and deficiencies in our knowledge about the region

Secondary objectives (added for the benefit of the Council on Environmental Quality)

- provision of general biological habitat descriptions for the two biographical (sic) regions including key species for each one

- provision of a list of life history data for all key species

8) Government

9) Environmental data: geological oceanography and hydrology, physical, chemical and meteorological oceanography; Systems ecology by habitat: phytoplankton, zooplankton, benthic invertebrates, macrophytes, fishes, birds and mammals; Unique and Endangered Environments: Rare, endangered, and threatened species; Environmental Quality;

Socio-Economic data: demography, petroleum, recreation transportation, fisheries, land and water use

10) 700 maps, graphs and diagrams at various scales but all conforming to the $81 / 2 \times 11$ inch format

11) Highly variable base information; maps are black and white, generally poor to medium quality

12) This study provided the basis for BLM's Environmental Impact Statements regarding oCS oil and gas development. 
1) SUMMARY OF ENVIRONMENTAL INFORMATION ON THE CONTINENTAL SLOPE

2) TRIGOM (The Research Institute of the Gulf of Maine)

3) Bureau of Land Management, Marine Minerals Division

4)

5) Unpublished document, Contract 08550-CT5-47. (May 1976), 4 vols., 1700 pp.

6) The continental slope between the 200 and 2000 meter isobaths from the U.S. - Canadian boundary to Cape Hatteras

7) To provide the Bureau of Land Management with a survey of the literature relating to this area for use in impact assessments relating to oil and gas explorations

8) Government

9) The environment (meteorology, physical, geological, chemical and biological oceanography, including in the latter phytoplankton, zooplankton, benthos, mekton and offshore birds, and finally, submarine canyons); the human impact on the region (environmental quality, fisheries, ocean transport and hazards, archaeological and historical sites)

10) 400 tables and figures, the latter at a variety of scales but all conforming to an $81 / 2 \times 11$ inch format.

11) Base information varies. Maps are black and white, often duplicated from the original source. Quality varies.

12) Volume 4 contains 3 appendices which include a review of research activities in the area and a discussion of ongoing and future efforts. This study amplifies the 1974 TRIGOM literature review for the continental shelf in the region. 
1) FINAL ENVIRONMENTAL STATEMENT, PROPOSED 1977 OUTER CONTINENTAL SHELF OIL AND GAS LEASE SALE OFFSHORE THE NORTH ATLANTIC STATES OCS SALE NO. 42

2) Bureau of Land Management, Department of the Interior

3) Same

4)

5) 5 volumes, 1683 pp., 20 appendices, and a Supplement volume of 337 pp.

6) Georges Bank and the Atlantic Coast from New Jersey to Nova Scotia

7) To assess the environmental impacts of leasing tracts of the outer continental shelf for oil and gas exploration.

8) Government and Industry

9) Subject matter - social, environmental and economic impacts of OCS gas and oil development on Georges Bank and on the New England Region

10) Great variety of maps contained in volumes $1 \& 2$ at all scales; Volume 5 consists of 7 "visuals" including 5 maps at circa 1:1,000,000 covering the area from New Jersey to Nova Scotia and showing the lease tracts, potential hazards, petroleum facilities, transport networks, bottom sediments, soil limitations for foundations and shallow excavations, soil orders, domestic fisheries resources, recreation and open space resources, vegetation, physiography, bedrock geology, tectonics and offshore geology. In addition "visual" 2 shows 12 monthly maps of inferred surface and bottom circulation at a scale of circa $1: 3,200,000$

11) Base information for the 5 visuals in Volume 5 includes the lease tract grid, latitude and longitude, continental outline, state and county boundaries, toponyms, three mile line, and the 50,100, 200, 400, and 1,000 meter isobath with additional lines at 1,000 meter intervals. Maps are multicolored and quality is good.

12) This voluminous report reaches far beyond Georges Bank in its interpretation of on-shore social and economic uses of the coast. Much of the data for the report derives from the TRIGOM study (1974); a shorter, updated version of this EIS was issued as an internal document, U.S. Department of the Interior, "Secretarial Issue Document OCS Sale No. 42, Georges Bank" (June 29, 1979). 
1) A SUMMARY AND ANALYSIS OF ENVIRONMENTAL INFORMATION ON THE CONTINENTAL SHELF FROM THE BAY OF FUNDY TO CAPE HATTERAS, (1977)

2) Center for Natural Areas (South Gardiner, Maine)

3) Bureau of Land Management

4)

5) BLM no. AA 550-CT6-45 (December 1977), 3 Volumes (volume 1 consists of Books 1-3), 3,000 pp.

6) Bay of Fundy to Cape Hatteras, seaward to 200 meter isobath, shoreward to extent of salt water intrusion and occurence up to $0.5 \mathrm{ppt}$.

7) a. provide published and unpublished materials, as well as data sources updating marine environmental information presented in TRIGOM (1974) and University of Rhode Island (1972-73).

b. "compile and integrate both laboratory and field data concerning the effects of petroleum hydrocarbons and trace metals on marine organisms."

c. "summarize and document ongoing oceanographic survey and research programs."

d. "compile sources of raw data and unanalyzed samples."

e. "identify data gaps in each topic area and recommend future studies to fill gaps." (p. I-2)

8) Government and science

9) Geology (nearshore \& offshore), meteorology, physical oceanography, chemistry (hydrocarbons, trace metals, nutrients, pesticides, \& radioactivity), phytoplankton, zooplankton, neuston, nekton, benthos, commercial fisheries, sport fisheries, benthic flora, marine mammals, marine birds, threatened or endangered species, microbiology, ocs uses, unique and endangered environments, toxicity.

10) 400 tables and 550 illustrations at all scales conforming to the $81 / 2 \mathrm{x}$ 11 inch format.

11) Maps are black line, poor to medium quality. Many are reproduced from the original sources.

12) The chapters in the inventory correspond to the subjects listed above and are generally organized both topically and regionally. The inventory itself is contained in Vol 1, books 1-3. Volume 2 contains a master bibliography (each chapter also contains a lengthy bibliography), an index and acknowledgements. Volume 3 contains appendices of ongoing research projects and data gaps, and it identifies the existence of unworked samples and other raw data. 
1) NEW ENGLAND OCS ENVIRONMENTAL BENCHMARK, DRAFT FINAL REPORT.

2) Energy Resources Company, Inc.

3) Bureau of Land Management

4)

5) Report submitted to the BLM under contract AA550-CT6-51, May 19, 1978, $13+$ Vols.

6) Georges Bank, part of the Gulf of Maine

7) to establish a survey of physical, biological, geological and chemical attributes of Georges Bank and adjacent areas for use in an ongoing monitoring program

8) Science and government

9) Biological, geological, physical and chemical oceanography

10) 223 maps, graphs and other figures at a variety of scales but conforming to an $81 / 2 \times 11$ inch format; standardized map series are shown at four to a page at circa $1: 4,000,000$ and one per page at circa 1: $2,200,000$.

11) Latitude and longitude ticks or graticule, continental outline (1imited to Cape Cod) with isobaths generalized from 30 to 1000 meters according to map scale. Maps are black and white and quality is generally poor. 
1) SUMMARY AND ANALYSIS OF CULTURAL RESOURCE INFORMATION ON THE CONTINENTAL SHELF FROM THE BAY OF FUNDY TO CAPE HATTERAS, FINAL REPORT

2) Michael Roberts, Randall Moir, Fussel Barber, Bruce Bourque all of the Institute for the Conservation Achaeology, Peabody Museum, Harvard University

3) Bureau of Land Management

4)

5) BLM contract no. AA 551-CT8 -18, 1979.

6) Continental shelf from Bay of Fundy to Cape Hatteras

7)

8) Government

9) Vo1. I: The Physical Environment; V01. II, Archaeology and Palaeontology; Vo1 III, Historic Shipping; Vo1. IV. Management

10) Volume I contains 116 figures, volume II has 24, volume III has 57 and volume IV has 60 , all on $81 / 2 \times 11$ inch format. Additional folded maps accompany the four volumes.

11) Maps vary in scale and base information. Maps are black and white of poor to medium quality.

12) N.B. - the entire study was not available for review for this report. Only copies of the tables of contents, lists of figures, and some text and figures were reviewed. Above all, the human occupation of the region is dealt with and paleogeographic environments are postulated with respect to sea level. 
1) DRAFT ENVIRONMENTAL IMPACT STATEMENT ON THE AGREEMENT BETWEEN THE UNITED STATES AND CANADA ON EAST COAST FISHERY RESOURCES .

2) U.S. Department of State

3) U.S. Departments of State and Commerce

4)

5) April 1980 (160 pp. plus 146 pp. of appendices)

6) Gulf of Maine - Georges Bank area specifically but coastal waters from New Foundland to Cape Hatteras genera1ly.

7) "...evaluates the environmental impact of ratifying and implementing the Agreement between the Government of the United States of America and the Government of Canada on East Coast Fishery Resources." (p. i)

8) Government

9) Fisheries management and U.S. - Canadian maritime boundary; maps are primarily of species distribution in Spring and Fall

10) 15 maps of species distribution and one map of surface currents on an $81 / 2 \times 11$ inch format at scale of $1: 10,800,000$

11) Base information includes latitude and longitude, continental out1ine, 100 fathom line, ICNAF subareas and divisions, and the three proposed maritime boundaries between the U.S. and Canada. The maps are good quality black, gray and white.

12) Appendix I contains the text of the proposed agreement between the U.S. and Canada. Annex A of this appendix specifies the terms of fishing access and entitlements of each country to the major fish stocks in the region. Appendix II contains a brief description of the distribution, life cycle, exploitation, management and current stock status of the 15 species mapped in the main text. Appendix III is a brief description of the natural environment of the boundary region, including submarine topography, currents, temperature, salinity, and biology. Finally, Appendix IV profiles the current status of commercial fisheries from Maine to Virginia by the state and major port. 
1) EASTERn UNIted STATES COASTAL AND OCEAN ZONES DATA ATLAS

2) G. Carleton Ray, M. Geraldine McCormick-Ray, James A. Dobbin, Charles N. Ehler and Daniel J. Basta

3) Council on Environmental Quality and Office of Coastal Zone Management, National Oceanic and Atmospheric Administration, US Department of Commerce

4)

5) August 1980

6) Atlantic coast and continental shelf offshore to the 200 mile fishery conservation zone from Nova Scotia to the Florida Keys including all coastal counties or areas below the 100 meter elevation, whichever extends further inland.

7) to provide "...a preliminary basis for identifying and better understanding some of the relationships between and among human activities and elements of the natural system as they interact in the coastal and ocean zones of the Eastern United States" in view of increasing demands on these areas.

8) Government and industry

9) Five categories (examples of topics mapped are in parentheses): 1) Physical Environments (geology, currents, surface temperatures, hurricane frequencies); 2) Living Environments (potential terrestial vegetation, forested and non-forested wetland, algae; 3) Species (divided into 7 maps of invertebrates, 30 of fishes, 2 of amphibians, 5 of reptiles, 18 of birds, 5 of mammals and 1 of endangered and threatened plants); 4) Economic Activities (including onshore: population distribution in 1970, petroleum refining, petrochemical plants, power plants, municipal wastewater plants, annual wastewater discharge, fecal coliform bacteria, phosphorous, and Kjelhl Nitrogen discharge; and offshore: OCS oil and gas activity, crude oil shipping and ports, petroleum products, oil spills, ocean dump sites, and shellfish closure areas); 5) Jurisdictions (political boundaries, state CZM boundaries, Environmental Quality Management Areas and protected areas).

10) 125 maps at ca. $1: 4,250,000$, ca. $22.5 \times 60 \mathrm{~cm}$.

11) base information includes latitude and longitude, continental outline, coastal county boundaries, 100 meter contour, the Fishery Conservation Zone (200 mile limit), and the following isobaths (in meters): 20, 40, $100,140,200,400,600,1000$ and so on at 400 meter intervals. Map quality is good with the land shown in gray, the water in blue and the data mapped in black line, symbol and pattern. 
(2) FISHERIES AND PETROLEUM 
1) FISHING AND PETROLEUM INTERACTIONS ON GEORGES BANK, VOLUME I: AREAS OF PARTICULAR INTEREST TO THE INDUSTRIES

2) Stephen B. Olsen and Saul B. Saila, University of Rhode Island, Coastal Resources Center

3) New England Regional Commission

4)

5) Energy Program Technical Report 76-3, January, 1926 (20 pp.)

6) Georges Bank and Nantucket Shoals (40 - 42 30' No and 6545 - 71 W.)

7) "...this preliminary report has been prepared to summarize available geographic information on the distribution and relative intensity or abundance of various activities and environmental characteristics that will be of help in evaluating the potential interactions between" the fishery and petroleum industries on Georges Bank. (p.1).

8) Government and industry

9) Areas of interest to petroleum industry; fishing activity; known spawning grounds; benthos distribution; surface sediments; surface currents

10) 13 maps ca. $39 \times 27 \mathrm{~cm}$. at ca. $1: 1,150,000$

11) Base information includes latitude and longitude, 10 minute grid identifying oil lease tracts, continental outline and $20,30,40,40,100$ and 1000 meter isobaths and marine toponyms. Cartographic quality is poor with numerous errors corrected in an addendum. Base map is black line with a green 10 minute grid and data mapped in red.

12) Vo1. II of this project bears the same title with the following subtitle: The Characteristics of the Two Industries, Potential Future Trends, and an Assessment of Foreseeable Conflict. (New England Regional Commission, Energy Program Technical Report 77-1, March, 1977). This volume contains a brief review of the literature concerning environmental conditions on Georges Bank and several sections devoted to the topics mentioned in the subtitle. 
1) EFFECTS ON COMMERCIAL FISHING OF PETROLEUM DEVELOPMENT OFF THE NORTH-EASTERN UNITED STATES

2) David W. Allen, Richard B. Allen, Robert E. Black, James M. Friedman, Lawrence G. Mallon, Robert W. Morse, Susan B. Peterson and Leah J. Smith

3) Marine Policy Program, WHOI

4) Woods Hole Oceanographic Institution

5) WHOI Report NO. 76-66, Apri1 1976

6) Mid Atlantic Bight and Georges Bank

7) to assess "...the interactions to be anticipated between a possible offshore petroleum industry and the domestic offshore commercial fishing industry off the East Coast."

8) General

9) Fishing areas and technologies; oil lease tracts and industry operations

10) 9 maps at a variety of scales and numerous additional sketches and diagrams on an $81 / 2 \times 11$ inch format

11) Varies widely; quality is medium to good

12) The study projects spatial use conflicts between fishermen and the lease tracts proposed 
1) REPORT ON FISHERIES RESOURCES IN THE GULF OF MAINE WITH PARTICULAR REFERENCE TO GEORGES BANK (NOVEMBER 23, 1977)

2) Jeffrey T. Lutz

3) U.S. Department of State

4)

5) Unpublished Memorandum to Ambassador Cutler, November 23, 1977

6) Gulf of Maine and Georges Bank

7) The report is part of the "continuing project on the assessment of resources within the areas covered by U.S. maritime boundary negotiations".

8) Government

9) Physiography, surface currents, U.S., Canadian and Soviet fishing activity, sea scallop harvest, general commercial fish catch on Georges Bank

10) 11 maps on $81 / 2 \times 11$ inch format at ca. $1: 5,830,000$

11) Base information includes latitude and longitude, 50, 100, 500, 1000 and 2000 fathom lines, continental outline, and major toponyms. Maps are good quality black and white with data mapped primarily in red.

12) The document was prepared during the course of negotiations over the U.S. Canada maritime boundary and resembles the Draft Environmental Impact Statement on the Agreement Between the United States and Canada on East Coast Fishery Resources (Department of State, April 1980), although the maps contained in it are not the same as those in the EIS. Major sources for this report were ICNAF statistics, NMFS Lab reports, Gusey (1977), the Final EIS for the Proposed 1977 OCS 011 and Gas Lease Sale Offshore the North Atlantic States, The Research Institute of the Gulf of Maine (1974), and 01sen and Saila (1977). 
1) ATLAS OF THE MAJOR ATLANTIC COAST FISH AND INVERTEBRATE RESOURCES ADJACENT TO THE CANADA - UNITED STATES BOUNDARY AREAS

2) G.M. Hare

3) Department of the Environment, Fisheries and Marine Service Research and Development Directorate (Canada)

4)

5) Technical Report 681 (1977), 97 pp.

6) Gulf of Maine, Georges Bank

7) To provide information of the distributions, stocks structures, species compositions, locations and landings of the major Atlantic coast fish and invertebrate resources in the area.

8) Government

9) Fisheries resources, distributions, landings and status of stocks of cod, haddock, redfish, pollock, silver hake, red and white hake, flounder, argentine, herring, mackerel, swordfish, bluefin tuna, squid, scallop, and lobster.

10) 21 sma11 scale maps of distributions (format ca. $7 \times 7 \mathrm{~cm}$, at $1: 26,000,000), 18$ cartograms with graphs of landings by ICNAF subareas and by period $(1953-54,1955-59,1960-64,1965-69, \& 1970-74$, as available), 6 maps (11 X8 cm. at $1: 4,150,000)$ of Canadian effort and yield on Georges Bank (ICNAF subdivision $5 \mathrm{Ze}$ ).

11) Maps are quite sma11, in black and white, with base information consisting of ICNAF subdivisions, latitude and longitude, continental outline, and 100 and 200 meter isobath.

12) Appendix one consists of landings by Canada, U.S.A., USSR, East European, Latin, and other countries in ICNAF Subareas 4, 5, and Statistical area 6 from 1953-1974; appendix two lists average annual landings and percentages or total landings of the same information. 
1) FISHERIES

2) J.L. McHugh and Jay J.C. Ginter

3) New York Sea Grant Institute

4)

5) Monograph 16, MESA New York Bight Atlas, January 1978 (pp. 129)

6) Northwest Atlantic from Cape Hatteras to Nova Scotia

7) To present the geography of fisheries in the Northwest Atlantic

8) Science and general public

9) "Historic Fish and Shellfish Landings and Trends" and "Foreign Fisheries"

10) The monograph is divided in two parts as indicated at point 9 above: part one shows 26 maps of fish yield by species at $1: 5,200,000$, part two contains 31 maps showing foreign fishing locations from 1969 through 1977 at the same scale; maps are on a $27 \times 19 \mathrm{~cm}$ format

11) Base information includes latitude and longitude ticks, continental outline, the 12 mile zone, and 200 meter isobath; the species catch maps show ICNAF statistical areas; maps are brown and blue with data mapped in black, brown and blue

12) This monograph complements monograph 15 which is now in press (Grosslein \& Azarovitz) 
1) "MASSACHUSETTS RECOMMENDATIONS, CALL FOR NOMINATIONS PROPOSED OCS SALE $52, "$ AND ACCOMPANYING LETTER FROM EDWARD KING, GOVERNOR OF MASSACHUSETTS TO R. FRANK GREGG, DIRECTOR, BUREAU OF LAND MANAGEMENT

2) Edward J. King, Governor of the Commonwealth of Massachusetts

3)

4)

5) Unpublished letter and accompanying graphics dated March 5, 1980

6) OCS Lease sale 非52 - Georges Bank and Nantucket Shoals

7) To illustrate reasons for recommendations of the Commonwealth of Massachusetts regarding inclusion or deletion of lease tracts on the OCS

8) Bureau of Land Management

9) Lease tracts, prime fishing grounds, spawning areas, fish landings by source region, value of landings by source region, oil spill risk, geologic hazards, tidal currents, fine grained sediment deposits

10) 9 maps at ca. $1: 1,233,000$ on a $39 \times 46 \mathrm{~cm}$ format

11) Base information shows lease tract graticule, continental outline, 60, 100 200, 2000 and 4000 meter isobath; maps are black and white, of medium quality

12) The maps do not list sources although occasional references are made in the accompanying letter. An appendage to the letter provides a survey of fish landings and value of these landings in Massachusetts by source region. 
1) FISHERY MANAGEMENT PLAN AND OUTER CONTINENTAL SHELF PETROLEUM DEVELOPMENT: DEFINING SENSITIVE HABITATS ON GEORGES BANK

2) Alison Reiser and Judith Spiller

3) Marine Policy and Ocean Management Program, WHOI

4)

5) Work in progress with maps (1980)

6) Georges Bank and Nantucket Shoals

7) To identify sensitive habitats, areas of fishing activity, and areas of potential oil exploration

8) Science and government

9) Spawning areas, fishing grounds by season, and bottom type

10) 7 maps, at ca. $1: 1,430,000$

11) Base information includes latitude and longitude, continental outline, $20,30,40,50,100,500$, and 1,000 fathom isobath, and oil lease tracts. Cartographic quality is poor to medium in black and white.

12) The manuscript report was not available for review. Only the maps were reviewed. 
(3) BIOLOGY 
1) A GEOGRAPHIC STUDY OF THE CLAM, SPISULA POLYNYMA (STIMPSON)

2) J. Lockwood Chamberlain and Franklin Stearns

3) Bureau of Commercial Fisheries Biological Laboratory

4) American Geographical Society

5) Serial Atlas of the Marine Environment, folio 3 (1963)

6) The North Pacific and the Northwest Atlantic from the New York Bight to the Grand Banks

7) Understanding of these two distributions

8) Science

9) Locality records of Spisula polynyma, maximum bottom temperature regions bottom sediment regions, regions postulated as suitable for $\underline{S}$. polynyma all in the Western north Atlantic

10) North Atlantic as shown on 4 maps at $1: 4,000,000$ on circa $32 \times 60 \mathrm{~cm}$; one detail of Cape Cod and Massachusetts Bay is shown at 1:500,000 on circa $28 \times 37 \mathrm{~cm}$.

11) Base information includes latitude and longitude graticule, continental areas, and 200 meter isobath; base map is gray with data mapped in green, blue, red and yellow; quality is good

12) This study is included even though it deals with a single species for two reasons. It is part of the broader map series of the American Geographical Society and therefore is not simply a sporadic occurence. Secondly, some attempt is made to postulate distributions based on temperature and sediment type rather than just report sample findings. 
1) AUTUMN DISTRIBUTION OF GROUNDFISH SPECIES IN THE GULF OF MAINE AND ADJACENT WATERS, 1951-1961

2) Raymond L. Fritz

3) National Science Foundation

4) American Geographical Society

5) Serial Atlas of the Marine Environment, folio 10, 1965

6) Gulf of Maine and Georges Bank

7) Data were gathered to estimate the strength of new year-classes of haddock

8) Science and government

9) Distribution of 20 groundfish species

10) 22 maps at $1: 2,500,000$ circa $27 \times 27 \mathrm{~cm}$.

11) Base information includes latitude and longitude graticule, continental outline, and 30,100, 200 and 1000 meter isobaths; map base is gray and blue with data mapped in brown.

12) Data based on half hour trawl samples. 
1) DISTRIBUTION AND BIOLOGY OF MYSIDS (CRUSTACEA, MYSIDACEA) FROM THE ATLANTIC COAST OF THE UNITED STATES IN THE NMFS WOODS HOLE COLLECTION

2) Roland L. Wigley and Bruce R. Burns

3) National Marine Fisheries Service, Woods Hole, Massachusetts

4)

5) Fishery Bulletin, Vo1. 69, No. 4 (1971), pp. 717-746.

6) Atlantic continental shelf from Nova Scotia to Florida

7) To present data on mysids gathered in samples collected from 1953 through 1969

8) Science

9) Mysid (representing 16 genera) distributions, relations with bottom sediments, and "other ecological information"

10) 2 maps of the Atlantic coast, 12 maps of the Georges Bank area and 5 additional maps, all at $1: 10,000,000$ on a circa $7 \times 9 \mathrm{~cm}$. format

11) Latitude and longitude ticks, continental outline and 100 and 1,000 meter isobaths; maps are black and white of medium quality

12) 
1) DISTRIBUTION OF FISH EGGS AND LARVAE IN CONTINENTAL SHELF WATERS, NOVA SCOTIA TO LONG ISLAND

2) John B. Colton, Jr. and Jeanne M. St. Onge

3) MARMAP, National Marine Fisheries Service

4) American Geographical Society

5) Serial Atlas of the Marine Environment, folio 23 (1974)

6) Continental shelf waters from Nova Scotia to Long Island

7) "...to provide background material for formulating the sampling design of the ichthyoplankton surveys of the Marine Resources Monitoring, Assessment, and Prediction (MARMAP) Program of NOAA".

8) Science and government

9) Monthly distribution of 27 species of fish larvae and eggs as available from sampling program.

10) 11 plates with 12 maps each at circa $1: 6,140,000$

11) Base information includes a latitude and longitude graticule, the continental outline, and 200 and 2000 meter isobaths; included in the base information for each of the maps of distributions is the extent of sampling coverage for that sampling period; each plate, consisting of twelve maps, includes a bathymetric map of the area at the same scale as the maps of distributions for reference use; maps are gray and blue with data shown in brown.

12) A table is included showing cruise numbers, sponsoring laboratory or organization, dates, and literature references. 
1) DISTRIBUTION OF SELECTED FISH SPECIES AND STATUS OF MAJOR FISHERIES IN THE NORTHWEST ATLANTIC

2) M.D. Grosslein and S.H. Clark

3) National Marine Fisheries Service, Northeast Fisheries Center, Woods Hole

4)

5) Unpublished document, Lab. Reference \# 76-12, (July 1976), pp. 171+

6) Atlantic Coast from Cape Hatteras to the Scotian Shelf

7) Provide background data for bilateral negotiations between the USA and Canada

9) Distribution of major commercial species with emphasis on the disputed area; includes historical sketch of major fisheries.

10) 6 maps of foreign fisheries at circa $1: 6,000,000 ; 114$ maps of species distribution, major commercial fishing grounds, and average annual landings at scales between $1: 4,700,000$ and $1: 6,000,000$, all on $81 / 2 \mathrm{X}$ 11 inch format.

11) Continental outline, ICNAF statistical areas and subdivisions, longitude and latitude, 100 fathom line. Quality is black line and generally poor.

12) Appendix 1 is a "Brief Historical Synopsis of Certain Northeast U.S. Fisheries", by Keith A. Smith and Fred L. 01son, Lab Reference No. 76-11. 
1) THE FISH AND WILDLIFE RESOURCES OF THE GEORGES BANK REGION

2) William F. Gusey

3) Environmental Affairs, She11 0il Company

4)

5) Houston: February, 1977 (553 pp•)

6) Georges Bank and Adjacent areas including entire Atlantic seaboard for some maps (primarily $40 \quad 45 \mathrm{~N}$ by $64-74$ W.)

7) Purpose of project: "...to determine what species are present, where they are within the Georges Bank region, when they are there, why they are there, i.e., breeding, nesting, wintering, migrating, how many there are, and the extent of utilization or other constraints that exist with regard to the population dynamics of those species for which data are available." (p.iii)

8) General

9) "A record of the diversity, dimension, and status of the fish and wildlife resources (in the Georges Bank area) is all that has been attempted." (p. iii) This included birds, mammals, and fishes.

10) Ca. 200 maps, graphs and drawings, all but one conforming to $81 / 2 \times 11$ inch format. Base map of Georges Bank is at ca. 1:4,400,000; smaller scales of entire Atlantic coast are used for bird range maps.

11) Black line maps with base information including latitude and longitude (5 degree grid), continental margin, and 100, 200, 1000 and 2000 meter isobaths. Drawings include sketches of marine mammals, fishing vessels, fish and shellfish. Circa 82 tables present data on bird species, sightings and populations, and on fish landings.

12) After a brief introduction to the North Atlantic coastal zone and estuarine systems the volume is divided into four chapters as follows: Chapter 1 - Birds of the Georges Bank Region (pp. 11-166); Chapter 2 Marine Mammals of the Georges Bank Region (pp. 167-212); Chapter 3 Threatened Species of the Georges Bank Region (pp. 213-230); and, Chapter 4 - Fishery Resources of the Georges Bank Region (pp. 231-542). A nine-page bibliography concludes the study. 
1) DISTRIBUTION OF DECAPOD CRUSTACEA OFF NORTHEASTERN UNITED STATES BASED ON SPECIMENS AT THE NORTHEAST FISHERIES CENTER, WOODS HOLE, MASSACHUSETTS.

2) Williams, Austin B. and Roland L. Wigley

3) National Marine Fisheries Service, NOAA

4)

5) NOAA Technical Report NMFS Circular 407, December 1977, 44 pp.

6) Continental shelf and slope from Chesapeake Bay to the Gulf of Maine.

7) To present findings of 25 years of samplings.

8) Government and science.

9) Decapod Crustacea distributions.

10) 57 maps at $1: 7,500,000$ on a $8 \times 18 \mathrm{~cm}$. format.

11) Latitude and longitude ticks, continental outline, main cities, and 100 and 1,000 meter isobath; maps are black and white of fair quality.

12) 
1) DISTRIBUTION OF GAMMARIDEAN AMPHIPODA (CRUSTACEA) ON GEORGES BANK

2) John L. Dickinson and Roland L. Wigley

3) Northeast Fisheries Center, Woods Hole Laboratory, National Marine Fisheries Service, NOAA.

4)

5 ) Unpublished manuscript, (1980) ca. 60 pp.

6) Georges Bank, bounded by $60 \mathrm{~W}$. 1ongitude and the 200 meter isobath.

7) Purpose of project: "...to provide information useful to both benthic ecologists and fisheries biologists interested in the Georges Bank ecosystem. Since amphipods are known to be sensitive to environmental alteration, the data presented in this report may also be useful as a baseline in the event of petroleum development on Georges Bank." (p.1)

8) Science and government

9) 97 species of gammaridean amphipods on Georges Bank, with 8 introductory maps showing sample stations, geological features, bathymetry, sediment type, bottom water temperature, amphipod biomass and density.

10) 8 introductory maps at $1: 2,075,000,72$ maps of distributions at ca. $1: 6,000,000$ and 6 summary maps of gammaridean concentrations at ca. $1: 6,000,000$.

11) Base information includes latitude and longitude, Cape Cod, and the 100 and 200 meter isobaths.

12) Based on the Benthic Dynamics Investigation of Northeast Fisheries Center at Woods Hole from collections of samples taken from 1953 to 1965. A companion study of the Middle Atlantic Bight Region was published in 1980 (Dickinson, J.J., R.L. Wigley, R.D. Brodeur, and S. Brown-Leger, as NOAA Technical Report NMFS SSRF - 741). Both studies include an annotated check-1ist of species, including information on geographic and bathymetric ranges, sediment preferences, and general ecology as information from the literature allowed. 
1) ECOLOGICAL DISTRIBUTION OF POLYCHAETOUS ANNELIDS OF GEORGES BANK

2) Don Maurer and Wayne Leathem

3)

4) College of Marine Studies, University of Delaware

5) CMS-1-80 (February 1980), pp. 180.

6) Georges Bank

7) "To quantitatively determine the seasonal distribution, density, diversity, and biomass of polychaetous annelids".

8) Science and government

9) General biotic measures of polychaetes, identification of top taxa, benthic feeding classifications, distributions, secondary production, role of polychaetes in the diet of marine demersal fish and role of physical and geological processes in shaping ecologically and economically important habitats.

10) 2 maps at circa $1: 4,250,000$ on a $15 \times 10 \mathrm{~cm}$. format; 4 seasonal dendrograms of site groups and species groups.

11) Latitude and longitude graticule, Cape Cod and the 10, 30, 40, 50, 100, 500 and 1000 meter isobaths; maps are black and white of poor quality.

12) The data for this study were collected by the Energy Resources Company (1978) under contract to the BLM in 1977; the same data are synthesized in D. Maurer and W. Leathem, "Dominant Species of Polychaetous Annelids of Georges Bank", Marine Ecology - Progress Series, Vol 3 (1980), pp. 135-144. 
1) DISTRIBUTION AND ABUNDANCE OF EAST COAST BIVALVE MOLLUSKS IN THE NMFS WOODS HOLE COLLECTION

2) Roger B. Theroux and Roland L. Wigley

3) Northeast Fisheries Center, Woods Hole Laboratory, NMFS

4)

5) Submitted for publication as NOAA Technical Report, Spec. Sci. Rept.-Fish., 694 pp॰, 121 figures, 327 tables (1980, in review)

6) Atlantic continental shelf from Nova Scotia to Florida

7) To present data and analyses of 109,000 specimens collected over 21 years

8) Science

9) Bivalve mollusk distributions, bathymetric range and sediment preferences

10) 2 introductory maps and 119 maps of species distributions at $1: 10,000,000$ on a $7 \times 25 \mathrm{~cm}$. format

11) Latitude and longitude ticks, continental outlines, 100, 1,000, and 4,000 meter isobaths; each map includes a sketch of the organisms mapped

12) A companion volume presents the raw data used for this report and includes the vesse, cruise number, station number and location, water depth, bottom type and sampling gear used; see Roger B. Theroux and Roland L. Wigley, Collection Data for U.S. East Coast Bivalve Mollusks in the Northeast Fisheries Center Specimen Reference Collection, Woods Hole, Massachusetts, Laboratory Reference No. 79-29 (Ju1y 20, 1979). 
1) RESOURCE MAPPING OF BENTHIC ORGANISMS ON GEORGES BANK IN THE VICINITY OF LEASE SALE 非 42 .

2) Thomas M. Leschine, Judith Spiller and R.E. Bowman.

3) Coastal Research Center, WHOI.

4) Unpublished, work in progress.

5) Study initiated September 1980.

6) Lease sale \#42 and vicinity on Georges Bank.

7) "...synthesize and map data collected by MMFS and others on the distribution of the benthic fauna in the region of oil and gas exploration on Georges Bank and the principle depositional sink for fine grained particles south of Nantucket."

8) Government and science.

9) Distribution of benthic organisms, relation to sediment types and role as food source for fish.

10) As yet undetermined.

11)

12) Principle emphasis of the study is on important benthic food sources for commercially valuable fish; the study will also seek to identify organisms particularly sensitive to pollutants which may result from oil and gas development. 
1) ECOLOGY OF MIDDLE ATLANTIC BIGHT FISH AND SHELLFISH

2) M.D. Grosslein and Tom Azarovitz.

3) National Marine Fisheries Service, Woods Hole

4) NY Sea Grant Institute

5) Monograph 15 in the MESA New York Bight Atlas Series, In press.

6) Middle Atlantic Bight, Georges Bank and the Gulf of Maine.

7) To present species distribution data not yet published from a "unique quantitative data base which represents a major addition to the knowledge needed for evaluating changes in marine fish populations." $(\mathrm{p} .6)$

8) Science and the general public.

9) Summary of the ecology of 43 species of fish and shellfish, impacts of fishing and pollution on these species, population change in relation to seasonal and long term temperature trends.

10) Circa 19 introductory maps of sampling sites, temperature, and larval distribution at an undetermined scale (and not always including Georges Bank); 43 additional pairs of maps showing Spring and Autumn distributions of fish taken in sample trawls; the latter maps will be produced at 1:6,500,000; format for all the maps is two to a $22 \times 32$ $\mathrm{cm}$. page.

11) Base information includes latitude and longitude ticks, continental outline and 100 and 1000 meter isobaths; map quality in this series is good with base maps printed in blue and brown and data shown in black.

12) This monograph has not yet been published and was reviewed in manuscript form; it complements monograph sixteen in the same series dealing with fisheries in area from Cape Hatteras to Nova Scotia. 
(4) GEOLOGY 
1) BOTTOM SEDIMENT OF GEORGES BANKS

2) Roland L. Wigley

3) U.S. Fish and Wildlife Service, Bureau of Commercial Fisheries, Biological Laboratory, Woods Hole, Ma.

4)

5) Journal of Sedimentary Petrology. Vol. 31, No. 2 (1961) pp. 165-188.

6) Georges Bank, bounded generally by 100 Fathoms and ca. 69 W.

7) To present data gathered for the study of benthic animal distributions

8) Science

9) Sediment particle size and distribution

10) 8 maps at co. $1: 4,750,000$ on a $11 \times 9 \mathrm{~cm}$. format, plus additonal graphs

11) Latitude and longitude ticks, continental outline; 30, 50 and 100 Fathom lines shown; quality is medium for black and white maps

12) 
1) ATLANTIC CONTINENTAL SHELF AND SLOPE OF THE UNITED STATES (including 14 monographs by various authors as follows)

A. K.0. Emery (1966), "Geologic Background"

B. Richard M. Pratt, (1968) "Physiography and Sediments of the Deep-Sea Basin"

C. Elazar Uchupi (1968) "Physiography"

D. Danie1 J. Stanley (1969), "Color of Marine Sediments"

E. Joseph E. Hazel (1970) "Ostracod zoogeography in the Southern Nova Scotia and Northern Virginian Fannel Provinces"

F. Thomas J.M. Schopf (1968), "Nineteenth Century Exploration"

G. David A. Ross (1970), "Heavy Minerals of the Continental Margin from Southern Nova Scotia to Northern New Jersey"

H. John Schlee and Richard M. Pratt (1970), "Gravels of the Northeastern Part"

I. Elazar Uchupi, (1970) "Shallow Structure"

J. John D. Milliman (1972), "Petrology of the Sand Fraction of Sediments, Northern New Jersey to Southern Florida"

K. James Van Allen Trumbul1 (1972) "Sand Size Fraction of Bottom Sediment, New Jersey to Nova Scotia"

L. John Schlee (1973), "Sediment texture of Northeastern Part."

M. Charles D. Hollister (1973), "Texture of Surface from New Jersey to Southern Florida"

N. R.L. Wigley and R.B. Theroux (1981), "Marine Macro benthic Invertebrate Fauna of the Middle Atlantic Bight Region: Faunal Composition and Quantitative Distribution

2) Varied

3) U.S. Geological Survey

4)

5) U.S. Geological Survey Professional Paper 529 - A through M

6)

7) To present the results of a comprehensive 5 year joint study conducted by USGS and WHOI 
8) Science and government

9) marine geology (topography, sedimentology, lithology, structure, mineralogy paleontology, geochemistry and economic geology), biology and hydrology

10) Over 200 figures in the text of the various monographs and circa 100 color plates of folded maps as addenda; among these are Uchupi's bathymetric maps of the Atlantic coast and 63 maps of species distributions in Hazel's monograph

11) Great variation

12) 
1) SEDIMENTS, STRUCTURAL FRAMEWORK, PETROLEUM POTENTIAL, ENVIRONMENTAL CONDITIONS, AND OPERATIONAL CONSIDERATION OF THE UNITED STATES NORTH ATLANTIC OUTER CONTINENTAL SHELF

2) J. Schlee, R.E. Mattick, D.J. Taylor, O.W. Girard, J. Grow, E.C. Rhodehemei W.J. Perry, Jr॰, K.C. Bayer, M. Furbush, C.P. Clifford, and J.A. Lees

3) U.S. Geological Survey

4)

5) U.S.G.S. Open File Report no. 75-353 (1975)

6) Area of lease sale 非2, focusing generally on Georges Bank

7) Response to a request from the Bureau of Land Management for a "...summary of the geology, potential mineral resources, estimated oil and gas reserves, potential environmental hazards, and operational considerations of the United States North Atlantic area for the possibility of an oil and gas lease sale."

8) Government

9) Geology and oil potential fo Georges Bank

10) 28 maps and figures of various scales but all conforming to the $81 / 2 \mathrm{x}$ 11 inch format; 4 separate plates of maps and diagrams (nominal scales were not stated on these and could not be determined from the microfiche copy)

11) Varied; many were reproduced from the original source

12) 
1) GULF OF MAINE SEDIMENT CHARACTERISTICS

2) Office of the Geographer, U.S. State Department

3)

4)

5) State Department Reference Numbers 2719 - 2732, 12-77 (1977)

6) Gulf of Maine and Georges Bank

7) Related to survey of physical environment of the region in connection with the U.S. - Canada maritime boundary negotiations

8) Government officials

9) Sediment characteristics, including sources and age, sand and grave1, $\%$ gravel in all surface sediments, \% mud, \% calcium carbonate, carbonate assemblages, heavy minerals in surface sediment sands and depth of sediment from selected periods

10) 14 maps at scales of $1: 5,700,000$ (maps were prepared for $81 / 2 \times 11$ inch format but were also printed all together on one large sheet)

11) base information includes latitude and longitude, continental outline, $50,100,500,1000$ and 2000 fathom lines. Map quality is good, with grey and green base carrying data in brown.

12) The sources for this series included The Research Institute of the Gulf of Maine (1974) and seismic data from WHOI geologists. 
1) SUMMARY REPORT OF THE SEDIMENTS, STRUCTURAL FRAMEWORK, PETROLEUM POTENTIAL AND ENVIRONMENTAL CONDITIONS OF THE UNITED STATES NORTHEASTERN ATLANTIC CONTINENTAL MARGIN

2) John S. Schlee, John M. Aaron, Mahlon M. Ball, Kim D. Klitgord, John A. Grow, Bradford Butman, and Michael H. Bothner

3) U.S.G.S.

4)

5) U.S.G.S. Open File Report No. 79-674, 1979, 26 pp.

6) Western part of Georges Bank

7) "To update and summarize the geological information concerning the area of the Atlantic Continental Shelf off the Northeastern United States" (p.1)

8) Science and government

9) Regional geology and geophysics, potential environmental hazards, oil and gas potential

10) 8 maps at various scales all on $81 / 2 \times 11$ inch format; 4 other figures

11) varies considerably; maps are black and white of medium quality

12) 
1) ENVIRONMENTAL CONDITIONS RELATING TO POTENTIAL GEOLOGIC HAZARDS, U.S. NORTHEASTERN ATLANTIC CONTINENTAL MARGIN

2) John M. Aaron, Bradford Butman, Michael H. Bothner, and Richard E. Sylwester

3) U.S. Geological Survey

4)

5) U.S.G.S. Miscellaneous Feild Studies, Map MF - 1193 (1980), 3 sheets

6) Georges Bank

7) To summarize data concerning geologic hazards in the North Atlantic lease area

8) Science and government

9) Currents, tidal action, sediment transport, sand waves, slumps, earthquake epicenters, etc.

10) 8 maps at $1: 2,000,000$ on a $30 \times 23 \mathrm{~cm}$ format; 5 additional maps at various scales with numerous diagrams and seismic profiles; all on large $(90 \times 190 \mathrm{~cm}$.) sheets

11) Base information on the 8 standard maps includes latitude and 1ongitude ticks, the continental outline, and the 60,100,200, 2000, 3000 meter isobaths; maps are black and white and quality is fair

12) 
1) ENVIRONMENTAL GEOLOGIC STUDIES IN THE GEORGES BANK AREA, UNITED STATES NORTHEASTERN ATLANTIC OUTER CONTINENTAL SHELF, 1975-1977

Containing the following chapters:

I) John M. Aaron, "Introduction"

II) John D. Milliman, Michael H. Bothner, and Carol M. Parmenter, "Seston in New England Shelf and Slope Waters, 1976-1977"

III) Michae1 H. Bothner, Elliot C. Spiker, Wayne M. Ferrebee, and Douglas L. Peeler, "Texture, Clay Mineralogy, Trace Metals, and Age of Cored Sediments"

IV) David W. Folger, Sally A. Woods, Michael H. Bothner, and Bradford Butman, "Submersible Observations on Georges Bank"

V) Ralph S. Lewis, Richard E. Sylwester, John M. Aaron, David C. Twitche11, and Kathryn M. Scanlon, "Shallow Sedimentary Framework and Related Potential Geologic Hazards of the Georges Bank Area"

2) John M. Aaron (editor)

3) U.S. Geological Survey (conducted in cooperation with the Bureau of Land Management)

4)

5) Open-File Report No. $80-240,1980$

6) Georges Bank

7) To summarize research activities by the USGS in the Georges Bank Area in accordance with Memorandum of Understanding AA55 -MU6-29 between the USGS and the BLM; the report covers the period from 1 September 1975 to 30 September 1977

8) Government

9) As in number 1 above

10) 22 pages of maps at a variety of scales conforming to an $81 / 2 \times 11$ inch format; numerous additional graphs, profiles and photographs in text and in attached larger sheets

11) Generally includes latitude and longitude ticks, the continental outline and the 60,100,200, 2000 and 3000 meter isobaths; maps are black and white, quality is medium

12) 3 appendices carry cruise reports with maps, data from the analysis of suspended matter, and from the analysis of cored samples 
1) GEOLOGY OF NEW ENGLAND PASSIVE MARGIN

2) James A. Austin, Jr., Elazar Uchupi, D.R. Shaughnessy III, and R.D. Ballard

3) WHOI

4)

5) The American Association of Petroleum Geologists Bulletin, Vo1. 64, No. 4 (Apri1 1980), pp. 501-526.

6) Continental Shelf from Long Island to the Scotian Shelf

7) "to describe crustal structures characteristics of the margin, to estimate the lithology and thickness of the sediments underlying the continental shelf, slope and upper rise; and to reconstruct the margin's evolution through time within the broad framework of plate tectonics"

8) Science

9) See 非

10) 14 maps at $1: 5,200,000$ on a $14 \times 12 \mathrm{~cm}$. format; 9 additional figures

11) Latitude and longitude graticule, continental outline, 100,200 1,000 and 2000 meter isobaths; maps are black and white, quality is good

12) This article was derived in part from James Albert Austin, Geology of the Passive Margin off New England, Ph.D. Dissertation submitted to WHOI-MIT, December 1978 
1) ENVIRONMENTAL GEOLOGIC STUDIES IN THE GEORGES BANK AREA, UNITED STATES NORTH EASTERN ATLANTIC OUTER CONTINENTAL SHELF, 1978-79

Containing the following chapters:

J.M. Aaron, Kathy Scanlon and Jack Hampson. "Report on Geologic Hazards of the Continental Slope off Georges Bank"

David Twitche11, "Bedform Distribution and Inferred Sand Transport on Georges Bank"

Michael H. Bothner and Peter P. Johnson, "210 PB in Sediment Cores from the Atlantic Continental Shelf: Estimates of Rates of Sediment Mixing"

John A. Moody and B. Butman, "Moored Current and Bottom Pressure Observations of the Semidiurnal Tide on Georges Bank and in the Mid-Atlantic Bight"

M.H. Bothner, C.M. Parmenter and J.D. Milliman, "Temporal and Spatial Variations in Suspended Matter in Continental Shelf and Slope Waters off the Northeastern United States: Georges Bank and Vicinity"

R.E. Miller, et. a1., "Residual Interstitial Gas Studies of Piston Cores from the North and Mid-Atlantic Outer Continental Slope Environment"

David C. Twitche11, et. a1., "Morphology and Processes Associated with the Accumulation of the Fine-Grained Sediment Deposit on the Southern New England Shelf"

Richard A. Slatter, "Submersible Observations of the Sea Floor Near the Proposed Georges Bank Lease Sites Along the North Atlantic Outer Continental Shelf and Upper Slope"

2) Dennis 0'leary (editor)

3) U.S. Geological Survey, Environmental Geologic Studies

4)

5) Forthcoming (1981) as a U.S.G.S. Open-File Report

6) Georges Bank and vicinity

7) To summarize data gathered by the U.S.G.S. on contract with the Bureau of Land Management

8) Government and science 
9) As listed above

10)

11)

12) The individual reports named above may be available individually before the final report is completed; these reports were not available for review 
1) SEA SURFACE TEMPERATURE REGIME IN THE WESTERN NORTH ATLANTIC 1953-1954

2) Robert L. Pyle

3) Bureau of Commercial Fisheries Laboratory, Washington, D.C., and the Atomic Energy Commission.

4) American Geographical Society

5) Folio 1 of The Serial Atlas of the Marine Environment, 1962.

6) The Atlantic coastal area from the Bahamas to Nova Scoita bounded generally by $70 \mathrm{~W}$. longitude north to $35 \mathrm{~N}$. latitude and north again along $65 \mathrm{~W}$.

7) To present sea surface temperature data in graphic form for marine research.

8) Science and government

9) Sea surface temperature including mean monthly, annual difference (1953-54), seasonal range, seasonal warming or cooling, seasonal maxima and minima.

10) 26 pairs of maps at $1: 10,000,000$ at ca. $31 \times 28 \mathrm{~cm}$.

11) Base information includes latidude and longitude, continental outline, and the 200 meter isobath; base map is yellow and white with data mapped in red, blue, and gray.

12) 
1) NORTH ATLANTIC TEMPERATURES AT A DEPTH OF 200 METERS

2) Elizabeth H. Schroeder

3)

4) American Geographical Society.

5) Folio 2 of the Serial Atlas of the Marine Environment (1963).

6) The North Atlantic from 0 to 80 North latitude.

7) To present 96,000 observations of temperature at 200 meters.

8) Science and government

9) Mean temperature, range, deviations from the mean and seasonal distribution of data, maxima, minima, number of observations, seasons represented for each unit area.

10) Maps at $1: 10,000,000$ and 4 maps at $1: 30,000,000$; format is ca. $35 \times 41 \mathrm{~cm}$.

11) Base information includes latitude and longitude graticule, continental outlines, and 200 meter isobath; map quality is good, with base in grey and data mapped in blue and red.

12) The appendix is a table of data sources by location (latitude and longitude) and including the average temperature, maximum and minimum, number of observations, and period of observations. 
1) SURFACE CIRCULATION ON THE CONTINENTAL SHELF OFF EASTERN NORTH AMERICA BETWEEN NEWFOUNDLAND AND FLORIDA

2) Dean F. Bumpus and Louis M. Lauzier

3)

4) American Geographical Society

5) Serial Atlas of the Marine Environment, folio 7 (1965).

6) Atlantic continental shelf waters from Florida to New Foundland.

7) Integrate drift bottle data collected from 1948 through 1962 into a graphic presentation.

8) Science

9) Surface circulation inferred from monthly drift bottle recovery; monthly recovery shown and seasonal circulation inferred.

10) 6 plates with 2 maps each at $1: 5,000,000$ on a $61 \times 17 \mathrm{~cm}$. format.

11) Base information includes latitude and longitude graticule, continental outline, and 200 meter isobath; base is blue and white with data mapped in shades of gray and pink.

12) The Appendix lists the number of drift bottles released and recovered by one degree quadrangles of latitude and longitude and by month. 
1) AVERAGE MONTHLY SEA-WATER TEMPERATURES NOVA SCOTIA TO LONG ISLAND, 1940-1959

2) John B. Colton, Jr. and Ruth R. Stoddard.

3) National Marine Fisheries Service, Northeast Fisheries Center, Woods Hole.

4) American Geographical Society.

5) Serial Atlas of the Marine Environment, folio 21 (1972)

6) Georges Bank, Gulf of Maine and surrounding areas between 64 and 72 degrees west and north of $39 \mathrm{~N}$.

7) To synthesize bathythermographic data gathered by numerous organizations.

8) Science and government

9) Average monthly temperatures at the surface, and at $10,20,30,40,50$, 75 , and 100 meters; monthly temperature profiles at one degree longitudinal intervals.

10) 8 plates with 12 maps each at $1: 6,000,000$ on a $58 \times 38 \mathrm{~cm}$. format, 2 plates with vertical temperature profiles.

11) Base information includes latitude and longitude graticule and continental outline; areas shallower than the depth for which data is presented are indicated; maps are gray and blue with data presented in blue isotherms; quality is medium.

12) An appendix shows the raw data summarized by 30 minute quaddrangles. 
1) BOTTOM-WATER TEMPERATURES ON THE CONTINENTAL SHELF, NOVA SCOTIA TO NEW JERSEY.

2) John B. Colton, Jr. and Ruth R. Stoddard

3) National Marine Fisheries Service, NOAA.

4)

5) NOAA Technical Report, NMFS CIRC-376, June 1973, 55 pp.

6) Continental shelf from Nova Scotia to New Jersey.

7) To synthesize data collected from 1940 to 1966.

8). Science and government

9) Mean monthly bottom-water temperatures and annual maximum and minimum.

10) 15 maps at circa $1: 9,400,000$ on a $11.5 \mathrm{x} 22 \mathrm{~cm}$. format.

11) Latitude and longitude grid, continental outline and 100, 200, and 1000 meter isobath; base is black and white with isotherms in red.

12) 35 pages of raw data accompany the paper. 
1) NEW ENGLAND OUTER CONTINENTAL SHELF PHYSICAL OCEANOGRAPHY QUARTERLY REPORTS AND ANALYSIS REPORTS.

2) EG\&G, Environmental Consultant

3) Bureau of Land Management.

4)

5) Progress reports to BLM for contract AA551-CT8-46, 13+ vo1. 1978-80.

6) Georges Bank and vicinity.

7) To identify and quantify physical processes involved in the transport and dispersion of suspended or dissolved material.

8) Science and government.

9) Data collection, presentation and analysis.

10) Many maps and other figures at a variety of scales on $81 / 2 \times 11$ inch formats and additonal fold-out sheets.

11) Base information varies widely; maps are black and white and of generally poor quality.

12) The quarterly reports consist of compilations of data. 
1) A CLIMATOLOGIC AND OCEANOGRAPHIC ANALYSIS OF THE GEORGES BANK REGION OF THE OUTER CONTINENTAL SHELF.

2) Godsha11, Fredric A., Robert G. Williams, Joseph M. Bishop, Fred Everdale, and Steven W. Fehler.

3) U.S. Department of Commerce, National Oceanic and Atmospheric Administration and Environmental Data and Information Service.

4)

5) Final report to the Bureau of Land Management, U.S. Department of the Interior, Interagency agreement AA551-1A8-14 (September, 1980), 290 pp.

6) Georges Bank, Gulf of Maine, Brown's Bank, and the Scotian Shelf.

7) To provide the Bureau of Land Mangement with a summary of historical data on meteorology and physical and chemical oceanography of the Georges Bank region for use in mineral management programs in the area and for environmental protection.

8) Government

9) Surface, wind, air temperature, visibility, bathythermograph data, ocean circulation, currents and mixing, hydrographic variable, surface waves, dissolved oxygen and nutrients.

10) Circa 70 maps at $1: 5,530,000$ and an additional 40 maps ranging in scale up to circa 1:12,000,000; in addition, numerous graphs, tables and histograms are used.

11) Base information includes latitude, longitude, and continental outline. Maps are black line.

12) The conclusion to the study includes a commentary on data limitations and recommendations for future analyses and for use of analytical procedures. 
1) THE MEAN CIRCULATION ON GEORGES BANK.

2) Bradford Butman, Robert C. Beardsley, Bruce Magne11, John A. Vermersch, Ronald J. Schlitz, Richard Limeburner, and Marlene A. Noble.

3)

4) Manuscript form.

5) Submitted to Science, February 1981 (26 pp॰t)

6) Georges Bank

7) To summarize results of research from 1975-79 on circulation on Georges Bank.

8) Science

9) Residual circulation.

10) 120 maps at various scales all conforming to $8 \times 11$ inch format.

11) Base includes latitude and longitude ticks, continental outline, and 60 , 100,200 , and 2000 meter isobaths; maps are good quality black and white.

12) Three tables summarize the data used. 
Discussion

A large number of the citations listed in this bibliography are studies or reports mandated by governmental regulations for use in the OCS leasing process or in the U.S. - Canadian boundary dispute. The audience for these reports is restricted primarily to government agencies and, to a lesser degree, to science. As a result of the mandates and the research they generated a few of the studies listed have been published in scientific journals. In general, however, the bulk of these studies are working government documents, a fact which is reflected in their overall quality, including that of the illustrations. With a few exceptions the remainder of the citations are directed to a scientifc audience.

The few works surveyed which are directed to a broader audience include the monographs of the Serial Atlas of the Marine Environment (Bumpus and Lauzier, 1965; Chamberlain and Stearns, 1963; Colton and St.Onge; 1974; Co1ton and Stoddard, 1972; Fritz, 1965; Pyle, 1962; and Schroeder, 1963) and the two monographs in the MESA New York Bight Atlas (Grosslein and Azarovitz, in press; and McHugh and Ginter, 1978). Nelther of these deal strictly with Georges Bank but monographs in each series do treat the region. The maps in these publications are better quality than those in most of the studies reviewed.

Besides the citations reviewed here two studies currently underway have come to my attention. One is D. Maurer's (University of Delaware) study of Georges Bank Benthic Invertebrates. This study will include a fairly detailed survey of the Georges Bank environment (Marine geology, physical oceanography and biology) before treating the benthos in detail. Apparently the study will 
also address the response of benthic invertebrates to pollutants on Georges Bank and the management implications of this pollution. The second work in progress is a Marine Resource and Environmental Atlas of the Bay of Fundy and the Gulf of Maine including Georges Bank. This atlas is being conpiled by the Ocean Studies Programme at Dalhousie University in Halifax. My understanding is that 42 maps of environmental features and of species distributions have been compiled. The project participants are not sure at this time of the final publication schedule. In addition to the atlas at least two monographs concerning the management of Georges Bank and the Gulf of Maine - Bay of Fundy are under way at Dalhousie. 


\section{BIBLIOGRAPHY}

This bibliography includes all the works reviewed in this survey as well as work in progress or in press. It also contains citations of studies used in the preparation of this report and citations of publications that are only mentioned. Asterisk (*) indicates citations which are not part of the annotated bibliography.

Aaron, John M• (ed•) 1980. ENVIRONMENTAL GEOLOGIC STUDIES IN THE GEORGES BANK AREA, UNITED STATES NORTH EASTERN ATLANTIC OUTER CONTINENTAL SHELF. U.S. Geological Survey• Open-File Rept. No. 80-240.

Aaron, John M., Bradford Butman, Michael H. Bothner, and Richard E. Sylwester. 1980. ENVIRONMENTAL CONDITIONS RELATING TO POTENTIAL GEOLOGIC HAZARDS, U.S. NORTHEASTERN ATLANTIC CONTINENTAL MARGIN. U.S. Geological Survey, Miscellaneous Field Studies, Map MF - 1193 ( 3 sheets).

*Austin, James Allen. 1978. GEOLOGY OF THE PASSIVE MARGIN OFF NEW ENGLAND. Unpublished Ph. D. Dissertation, WHOI-MIT, December.

Austin, James A., Jr., Elazar Uchupi, D.R. Shaughnessy, III, and R.D. Ballard 1980. GEOLOGY OF NEW ENGLAND PASSIVE MARGIN, The American Association of Petroleum Geologists Bulletin, Vol. 64, no. 4, pp. $501-526$.

Bumpus, D.F. and L.M. Lauzier. 1965. SURFACE CIRCULATION ON THE CONTINENTAL SHELF OFF EASTERN NORTH AMERICA BETWEEN NEWFOUNDLAND AND FLORIDA. American Geographical Society. Serial Atlas of the Marine Environment. folio 7 .

Butman, Bradford, Robert C. Beardsley, Bruce Magne11, John A. Vermersch, Ronald J. Schlitz, Richard Limeburner, and Marlene A. Noble. 1981. THE MEAN CIRCULATION ON GEORGES BANK. Submitted to Science. 26 pp.t.

Center for Natural Areas (South Gardiner, Maine). 1977. A SUMMARY AND ANALYSIS OF ENVIRONMENTAL INFORMATION ON THE CONTINENTAL SHELF FROM THE BAY OF FUNDY TO CAPE HATTERAS. Bureau of Land Management. BLM No. AA 550-CT6-45, 3 Volumes. 3,000 pp.,

Chamberlain, J. Lockwood and Franklin Stearns. 1963. A GEOGRAPHICAL STUDY OF THE CLAM, SPISULA POLYNYMA (STIMPSON), American Geographical Society, Serial Atlas of the Marine Environment, folio 3.

Colton, John B. Jr., and Jeanne M. St. Onge. 1974. DISTRIBUTION OF FISH EGGS AND LARVAE IN CONTINENTAL SHELF WATERS, NOVA SCOTIA TO LONG ISLAND. American Geographical Society, Serial Atlas of the Marine Environment, folio 23. 
Colton, John, B. Jr., and Ruth R. Stoddard. 1972. AVERAGE MONTHLY SEAWATER TEMPERATURES NOVA SCOTIA TO LONG ISLAND, 1940 - 1959.

American Geographical Society, Serial Atlas of the Marine Environment, folio 21 .

1973. BOTTOM-WATER TEMPERATURES ON THE CONTINENTAL SHELF, NOVA SCOTIA TO NEW JERSEY. National Marine Fisheries Service, NOAA. NOAA Technica1 Report, NMFS CIRC-376, 55p.

*Connor, Michael S. and Robert W. Howarth. 1977. POTENTIAL EFFECTS OF OIL PRODUCTION ON GEORGES BANK COMMUNITIES: A REVIEW OF THE DRAFT ENVIRONMENTAL IMPACT STATEMENT FOR OUTER CONTINENTAL SHELF OIL AND GAS LEASE SALE NO. 42. Woods Hole Oceanographic Institution Technical Report WHOI-77-1, January.

*Dickinson, John, J., Roland L. Wigley, Richard D. Brodeur, and Susan Brown-Leger . 1980. DISTRIBUTION OF GAMMARIDEAN AMPHIPODA (CRUSTACEA) IN THE MIDDLE ATLANTIC BIGHT. National Marine Fisheries Service, NOAA, Technical Report NMFS SSRF-741.

Dickinson, John L., and Roland L. Wigley. In press. DISTRIBUTION OF GAMMARIDEAN AMPHIPODA (CRUSTACEA) ON GEORGES BANK. National Marine Fisheries Service, Woods Hole, NOAA Technical Report, 60 pp.

EG \& G, Environmental Consultants. 1978 - Present. NEW ENGLAND OUTER CONTINENTAL SHELF PHYSICAL OCEANOGRAPHY, QUARTERLY REPORTS AND ANALYSIS REPORTS. Bureau of Land Management. Contract AA551-CT8-46.

Emery K.0. 1966. ATLANTIC CONTINENTAL SHELF AND SLOPE OF THE UNITED STATES, GEOLOGIC BACKGROUND. U.S. Geological Survey Professional Paper 529-A.

Energy Resources Company, Inc. 1978. NEW ENGLAND OCS ENVIRONMENTAL BENCHMARK DRAFT FINAL REPORT. Bureau of Land Management. Contract AA550-CT6-51.

Fritz, Raymond L. 1965. AUTUMN DISTRIBUTION OF GROUNDFISH SPECIES IN THE GULF OF MAINE AND ADJACENT WATERS, 1951 - 1961. American Geographica1 Society, Serial Atlas of the Marine Environment, folio 10.

Godsha11, Frederic A., Robert G. Williams, Joseph M. Bishop, Fred Everdale, and Steven W. Fehler. 1980. A CLIMATOLOGIC AND OCEANOGRAPHIC ANALYSIS OF THE GEORGES BANK REGION OF THE OUTER CONTINENTAL SHELF. U.S. Dept. of Commerce, NOAA and Environmental Data and Information Service final report to the BLM, U.S Dept. of the Interior, Interagency agreement AA551-1A8-14, 290 pp.

Grosslein, M.D. and T. Azarovitz (editors). In press. ECOLOGY OF MIDDLE ATLANTIC BIGHT FISH AND SHELLFISH. N.Y. Sea Grant Institute. Monograph 15 in the MESA New York Bight Altas Series.

Grosslein, M.D. and S.H. Clark. 1976. DISTRIBUTION OF SELECTED FISH SPECIES AND STATUS OF MAJOR FISHERIES IN THE NORTHWEST ATLANTIC. Unpublished document, Lab. Ref. 非76-12, National Marine Fisheries Service, Woods Hole, MA. pp. 171+. 
Gusey, William F. 1977. THE FISH AND WILDLIFE RESOURCES OF THE GEORGES BANK REGION. Shell 0il Company, Houston, 553 pp.

Hare, G.M. 1977. ATLAS OF THE MAJOR ATLANTIC COAST FISH AND INVERTEBRATE RESOURCES ADJACENT TO THE CANADA - UNITED STATES BOUNDARY AREAS. Department of the Environment, Fisheries and Marine Service Research and Development Directorate (Canada), Technical Report 681, 97 pp.

Haze1, Joseph E. 1970. ATLANTIC CONTINENTAL SHELF AND SLOPE OF THE UNITED STATES, OSTRACOD ZOOGEOGRAPHY IN THE SOUTHERN NOVA SCOTIA AND NORTHERN VIRGINIAN FANNEL PROVIENCES. U.S. Geological Survey Professional Paper 529-E.

Hollister, Charles D. 1973. ATLANTIC CONTINENTAL SHELF AND SLOPE OF THE UNITED STATES, TEXTURE OF SURFACE FROM NEW JERSEY TO SOUTHERN FLORIDA. U.S. Geological Survey Professional Paper 529-M.

King, Edward J., Governor of the Commonwealth of Massachusetts. 1980. MASSACHUSETTS RECOMMENDATIONS, CALL FOR NOMINATIONS PROPOSED OCS SALE 52, and accompanying letter from Edward J. King, Governor of Massachusetts to R. Frank Gregg, Director of BLM. Unpublished letter and eight accompanying maps. (March 5, 1980).

Leschine, Thomas, Judith Spiller and R.E. Bowman. In progress. RESOURCE MAPPING OF BENTHIC ORGANISMS ON GEORGES BANK IN THE VICINITY OF LEASE SALE 非2. Coastal Research Center, WHOI.

Maurer, Don and Wayne Leathem. 1980. ECOLOGICAL DISTRIBUTION OF POLYCHAETOUS ANNELIDS OF GEORGES BANK. College of Marine Studies, University of Delaware, CMS-1-80.

* 1980. DOMINANT SPECIES OF POLYCHAETOUS ANNELIDS OF GEORGES BANK. Marine Ecology - Progress Series, 3: 135-144.

McHugh, J.L. and Jay J.C. Ginter. 1978. FISHERIES. New York Sea Grant Institute, MESA New York Bight Atlas Monograph 16.

0'Leary, Dennis (ed.). In preparation. ENVIRONMENTAL GEOLOGIC STUDIES IN THE GEORGES BANK AREA, UNITED STATES NORTH EASTERN ATLANTIC OUTER CONTINENTAL SHELF. To be issued as a USGS open-file report.

01sen, Stephen B., and Saul B. Saila. 1976. FISHING AND PETROLEUM INTERACTIONS ON GEORGES BANK, Vo1. 1: AREAS OF PARTICULAR INTEREST TO THE INDUSTRIES. New England Regional Commission, Energy Program Technical Report 76-3.

1977. FISHING AND PETROLEUM INTERACTIONS ON GEORGES BANK, VOL. II, THE CHARACTERISTICS OF THE TWO INDUSTRIES, POETNTIAL FUTURE TRENDS, AND AN ASSESSMENT OF FORESEEABLE CONFLICT. New England Regional Commission, Energy Program Technical Report 77-1.

Pratt Richard M. 1968. ATLANTIC CONTINENTAL SHELF AND SLOPE OF THE UNITED STATES, PHYSIOGRAPHY AND SEDIMENTS OF THE DEEP-SEA BASIN.

U.S. Geological Survey Professional Paper 529-B. 
Pyle, Robert L. 1962. SEA SURFACE TEMPERATURE REGIME IN THE WESTERN NORTH ATLANTIC 1953-1954. American Geographical Society, The Serial Atlas of the Marine Environment, folio 1.

Ray, G. Carleton, M. Geraldine McCormick-Ray, James A. Dobbin, Charles N. Ehler and Daniel J. Basta. 1980. EASTERN UNITED STATES COASTAL AND OCEAN ZONES DATA ATLAS. Council on Environmental Quality and office of Coastal Zone Management, NOAA, U.S. Dept. of Commerce.

Ross, David A. 1970. ATLANTIC CONTINENTAL SHELF AND SLOPE OF THE UNITED STATES, HEAVY MINERALS OF THE CONTINENTAL MARGIN FROM SOUTHERN NOVA SCOTIA TO NORTHERN NEW JERSEY. U.S. Geological Survey Professional Paper 529-G.

Rieser, ALison and Judith Spiller. 1980. FISHERY MANAGEMENT PLAN AND OUTER CONTINENTAL SHELF PETROLEUM DEVELOPMENT: DEFINING SENSITIVE HABITATS ON GEORGES BANK. Marine Policy and Ocean Management Program, WHOI, work in progress.

Roberts, Michael, Randall Moir, Russel Barber, Bruce Bourque, Institute for Conservation Archaeology, Peabody Museum, Harvard University. 1979. SUMMARY AND ANALYSIS OF CULTURAL RESOURCE INFORMATION ON THE CONTINENTAL SHELF FROM THE BAY OF FUNDY TO CAPE HATTERAS, FINAL REPORT. BLM contract no. AA 551-CT8-18.

Schlee John. 1973. ATLANTIC CONTINENTAL SHELF AND SLOPE OF THE UNITED STATES, SEDIMENT TEXTURE OF NORTHEASTERN PART. U.S. Geological

Survey Professional Paper 529-L.

Schlee, John S., John M. Aaron, Mahlon M. Ba11, Kim D. Klitgord, John A. Grow, Bradford Butman, and Michael H. Bothner. 1979. SUMMARY REPORT OF THE SEDIMENTS, STRUCTURAL FRAMEWORK, PETROLEUM POTENTIAL, AND ENVIRONMENTAL CONDITIONS OF THE UNITED STATES NORTHEASTERN ATLANTIC CONTINENTAL MARGIN. U.S. Geological Survey, Open-File Report No. 79-674, 26 pp.

Schlee, J., R.E. Mattick, D.J. Taylor, O.W. Girard, J. Grow, E.C. Rhodeheme1, W.J. Perry, Jr., K.C. Bayer, M. Furbush, C.P. Clifford, and J.A. Lees, 1975. SEDIMENTS, STRUCTURAL FRAMEWORK, PETROLEUM POTENTIAL, ENVIRONMENTAL CONDITIONS, AND OPERATIONAL CONSIDERATIONS OF THE UNITED STATES NORTH ATLANTIC OUTER CONTINENTAL SHELF. U.S. Geological Survey, U.S.G.S. Open File Rept. no. 75-353.

Schlee John and Richard M. Pratt. 1970. ATLANTIC CONTINENTAL SHELF AND SLOPE OF THE UNITED STATES, GRAVELS OF THE NORTHEASTERN PART.

U.S. Geological Survey Professional Paper 529-H.

Schopf Thomas J.M. 1968. ATLANTIC CONTINENTAL SHEL AND SLOPE OF THE UNITED STATES, NINETEENTH CENTURY EXPLORATION. U.S. Geological Survey Professional Paper 529-F。

Schroeder, Elizabeth H. 1963 NORTH ATLANTIC TEMPERATURES AT A DEPTH OF 200 METERS, American Geographical Society, Serial Atlas of the Marine Environment, Folio 2 . 
*Smith, Keith A. and Fred L. 01son, 1976. BRIEF HISTORICAL SYNOPSIS OF CERTAIN NORTHEAST U.S. FISHERIES • Unpublished document, Lab. Ref . \#16-11, National Marine Fisheries Service, Woods Hole, MA.

Stanley, Daniel J. 1969. ATLANTIC CONTINENTAL SHELF AND SLOPE OF THE UNITED STATES, COLOR OF MARINE SEDIMENTS. U.S. Geologica1 Survey Professional Paper 529-D.

*Theroux, R.B. (in preparation). DISTRIBUTION AND ABUNDANCE OF THE DEEPWATER MEGAFAUNA ALONG THE U.S. EAST COAST CONTINENTAL SHELF AND SLOPE BETWEEN BALTIMORE AND CORSAIR CANYONS, NMFS, Woods Hole, MA.

*Theroux, R.B. and R.L. Wigley. In review. DISTRIBUTION AND ABUNDANCE OF EAST COAST BIVALVE MOLLUSKS IN THE NMFS WOODS HOLE COLLECTION.

Submitted for publication in NOAA Tech. Rept. Spec. Sc1. Rept.-Fish 694 pp., 121 figures.

TRIGOM (The Research Institute of the Gulf of Maine). 1974. A SOCIOECONOMIC AND ENVIRONMENTAL INVENTORY OF THE NORTH ATLANTIC REGION SANDY HOOK TO BAY OF FUNDY. BLM, Marine Minerals Div. Contract 08550-CT3-8. 4,900 pp. in 3 volumes.

1976. SUMMARY OF ENVIRONMENTAL INFORMATION ON THE CONTINENTAL SLOPE. Unpublished document, Contract 08550-CT5-47.

Trumbu11, James Van Allen. 1972. ATLANTIC CONTINENTAL SHELF AND SLOPE OF THE UNITED STATES, SAND SIZE FRACTION OF BOTTOM SEDIMENT, NEW JERSEY TO NOVA SCOTIA. U.S. Geological Survey Professional Paper 529-K.

U.S. Dept. of the Interior, BLM. 1976. FINAL ENVIRONMENTAL STATEMENT, PROPOSED 1977 OUTER CONTINENTAL SHELF OIL AND GAS LEASE SALE OFFSHORE THE NORTH ATLANTIC STATES OCS SALE NO. 42. BLM, 5 volumes, 1683 pp., 20 appendices, and a Supplement volume of 337 pp.

*U.S. Department of the Interior, 1979 SECRETARIAL ISSUE DOCUMENT OCS SALE NO. 42, GEORGES BANK. Unpublished document for internal use, (June 19).

*U.S. Department of the Interior, BLM. 1981. SYNOPIS OF ENVIRONMENTAL REPORTS FROM THE ENVIRONMENTAL STUDIES PROGRAM AND THE NEW YORK OCS OFFICE. Prepared by the Studies Staff, New York OCS Office.

U.S. Dept. of State, Office of Geographer. 1977. GULF OF MAINE SEDIMENT CHARACTERISTICS (Map Series). State Dept. Ref. Numbers 2719 - 2732, 12-77.

U.S. Dept. of State. 1980. DRAFT ENVIRONMENTAL IMPACT STATEMENT ON THE AGREEMENT BETWEEN THE UNITED STATES AND CANADA ON EAST COAST FISHERY RESOURCES. U.S. Dept. of State and Commerce (160 pp. plus 146 pp. of appendices).

U.S. Dept. of State, Jeffrey T. Lutz. 1977. REPORT ON FISHERIES RESOURCES IN THE GULF OF MAINE WITH PARTICULAR REFERENCE TO GEORGES BANK. Unpublished Memorandum to Ambassador Cutler, Nov• 23, 1977. 
U.S. Geologica1 Survey. 1966-1973. ATLANTIC CONTINENTAL SHELF AND SLOPE OF THE UNITED STATES, U.S. Geogogical Survey Professional Paper 529 - A through $\mathrm{N}$ :

A. K.0. Emery. 1966. GEOLOGIC BACKGROUND.

B. Richard M. Pratt. 1968. PHYSIOGRAPHY AND SEDIMENTS OF THE DEEP-SEA BASIN.

C. Elazar Uchupi. 1968. PHYSIOGRAPHY。

D. Daniel J. Stanley. 1969. COLOR OF MARINE SEDIMENTS.

E. Joseph E. Haze1. 1970. OSTRACOD ZOOGEOGRAPHY IN THE SOUTHERN NOVA SCOTIA AND NORTHERN VIRGINIAN FAUNAL PROVINCES.

F. Thomas J.M. Schopf. 1968. NINETEENTH CENTURY EXPLORATION .

G. David A. Ross. 1970. HEAVY METALS OF THE CONTINENTAL MARGIN FROM SOUTHERN NOVA SCOTIA TO NORTHERN NEW JERSEY.

H. John Schlee and Richard M. Pratt. 1970. GRAVELS OF THE NORTHEASTERN PART.

I. Elazar Uchupi. 1970. SHALLOW STRUCTURE.

J. John D. Milliman. 1972. PETROLOGY OF THE SAND FRACTION OF SEDIMENTS, NORTHERN NEW JERSEY TO SOUTHERN FLORIDA.

K. James Van Alan Trumbul1. 1972. SAND SIZE FRACTION OF BOTTOM SEDIMENTS, NEW JERSEY TO NOVA SCOTIA.

L. John Schlee. 1973. SEDIMENT TEXTURE OF NORTHEASTERN PART.

M. Charles D. Hollister. 1973. TEXTURE OF SURFACE SEDIMENTS FROM NEW JERSEY TO SOUTHERN FLORIDA.

N. R.L. Wigley and R.B. Theroux. 1980. MARINE MACRO BENTHIC INVERTEBRATE FAUNA OF THE MIDDLE ATLANTIC BIGHT REGION: FAUNAL COMPOSITON AND QUANTITATIVE DESTRIBUTION.

Uchupi Elazar. 1968. ATLANTIC CONTINENTAL SHEL AND SLOPE OF THE UNITED STATES, PHYSIOGRAPHY。U.S. Geological Survey Professional

Paper 529-C.

*University of Rhode Island (URI), Marine Experiment Station, Graduate School of Oceanography. 1973. COASTAL AND OFFSHORE ENVIRONMENTAL INVENTORY, CAPE HATTERAS TO NANTUCKET SHOALS. Marine Publications Series No. 2. Kingston, R.I., URI.

* 1974. COASTAL AND OFFSHORE ENVIRONMENTAL INVENTORY, CAPE HATTERAS TO NANTUCKET SHOALS. Marine Publications Series No. 3, Kingston, R.I. URI.

* 1977. GEORGES BANK OUTER CONTINENTAL SHELF ENVIRONMENTAL STUDIES WORKSHOP, A DISCUSSION OF THE BUREAU OF LAND MANAGEMENT'S GEORGES BANK ENVIRONMENTAL STUDIES PROGRAM. Report of a meeting April 4.

*Watling, L. and R. B. Theroux (in preparation). DISTRIBUTION OF CUMACEA (CRUSTACEA) IN THE OFFSHORE NEW ENGLAND REGION.

*Wigley, R.L. and R.B. Theroux. 1981 (in press). MARINE MACROBENTHIC INVERTEBRATE FAUNA OF THE MIDDLE ATLANTIC BIGHT REGION: FAUNAL COMPOSITION AND QUANTITATIVE DISTRIBUTION. U.S. Geol. Surv. Prof. Papers. Ser., 529 Chap. N. 374 p.

*Wigley, R.L. and R.B. Theroux (in preparation). QUANTITATIVE COMPOSITION AND DISTRIBUTION OF MACROBENTHIC INVERTEBRATES OF THE GEORGES BANK-GULF OF MAINE REGION. 
Wigley R.L. and R.B. Theroux. 1981. ATLANTIC CONTINENTAL SHELF AND SLOPE OF THE UNITED STATES, MARINE MACRO BENTHIC INVERTEBRATE FAUNA OF THE MIDDLE ATLANTIC BIGHT REGION: FAUNAL COMPOSITION AND QUANTITATIVE DISTRIBUTION". U.S. Geological Survey Professional Paper 529-N.

Williams, Austin B. and R.L. Wigley. 1977. DISTRIBUTION OF DECAPOD CRUSTACEA OFF NORTHEASTERN UNITED STATES BASED ON SPECIMENS AT THE NORTHEAST FISHERIES CENTER, WOODS HOLE, MASSACHUSETTS. National Marine Fisheries Service, NOAA. NOAA Technical Report NMFS Circular 407, 44pp. 


\begin{tabular}{|c|c|c|c|}
\hline $\begin{array}{l}\text { REPORT DOCUMENTATION } \\
\text { PAGE }\end{array}$ & $\begin{array}{l}\text { 1. REPORT NO. WHOI }-81-46 \\
\end{array}$ & 2. & 3. Recipient's Accession No. \\
\hline \multicolumn{3}{|c|}{$\begin{array}{l}\text { 4. Title and subtitle } \\
\text { GEORGES BANK: AN ANNOTATED BIBLIOGRAPHY } \\
\text { OF ATLASES, INVENTORIES AND MAP SERIES }\end{array}$} & $\begin{array}{l}\text { 5. Report Date } \\
\text { May } 1981 \\
\end{array}$ \\
\hline \multicolumn{3}{|l|}{$\begin{array}{l}\text { 7. Author(s) } \\
\text { Richard L. Price }\end{array}$} & 8. Performing Oreanization Rept. No. \\
\hline \multicolumn{3}{|c|}{$\begin{array}{l}\text { 9. Performing Organization Name and Address } \\
\text { Woods Hole Oceanographic Institution } \\
\text { Woods Hole, Massachusetts } 02543\end{array}$} & $\begin{array}{l}\text { 10. Projoct/Task/Work Unit No. } \\
\text { 11. Contract(C) or Grant(G) No. } \\
\text { (C) } \\
\text { (G) *NA } 80 A A-D-00077\end{array}$ \\
\hline \multirow{2}{*}{\multicolumn{3}{|c|}{$\begin{array}{l}\text { 12. Sponsoring Oreanization Name and Address } \\
\text { *Department of Commerce, NOAA Office of Sea Grant }\end{array}$}} & $\begin{array}{l}\text { 13. Type of Report \& Period Covered } \\
\text { Technical }\end{array}$ \\
\hline & & & 14. \\
\hline
\end{tabular}

15. Supplementary Notes

This report was also funded by the Pew Memorial Trust and the Mellon Foundation.

16. Abstract (Limit: 200 words)

The bibliography reviews inventory-like studies of the Georges Bank region and presents information on the scope of the work, topics treated, geographic area of concern, and audience. The primary purpose was to evaluate the nature and type of maps used in the works reviewed so the notations include the number of maps, their formats and scales, cartographic quality and base map content.

17. Document Analysis a. Descriptors

1. Georges Bank

2. Atlases and Inventories

3. Annotated Bibliography

b. Identifiers/Open-Ended Terms

c. COSATI Field/Group

19. Security Class (This Report)

Unclassified

20. Security Class (This Page)
21. No. of Pages 71 22. Price 


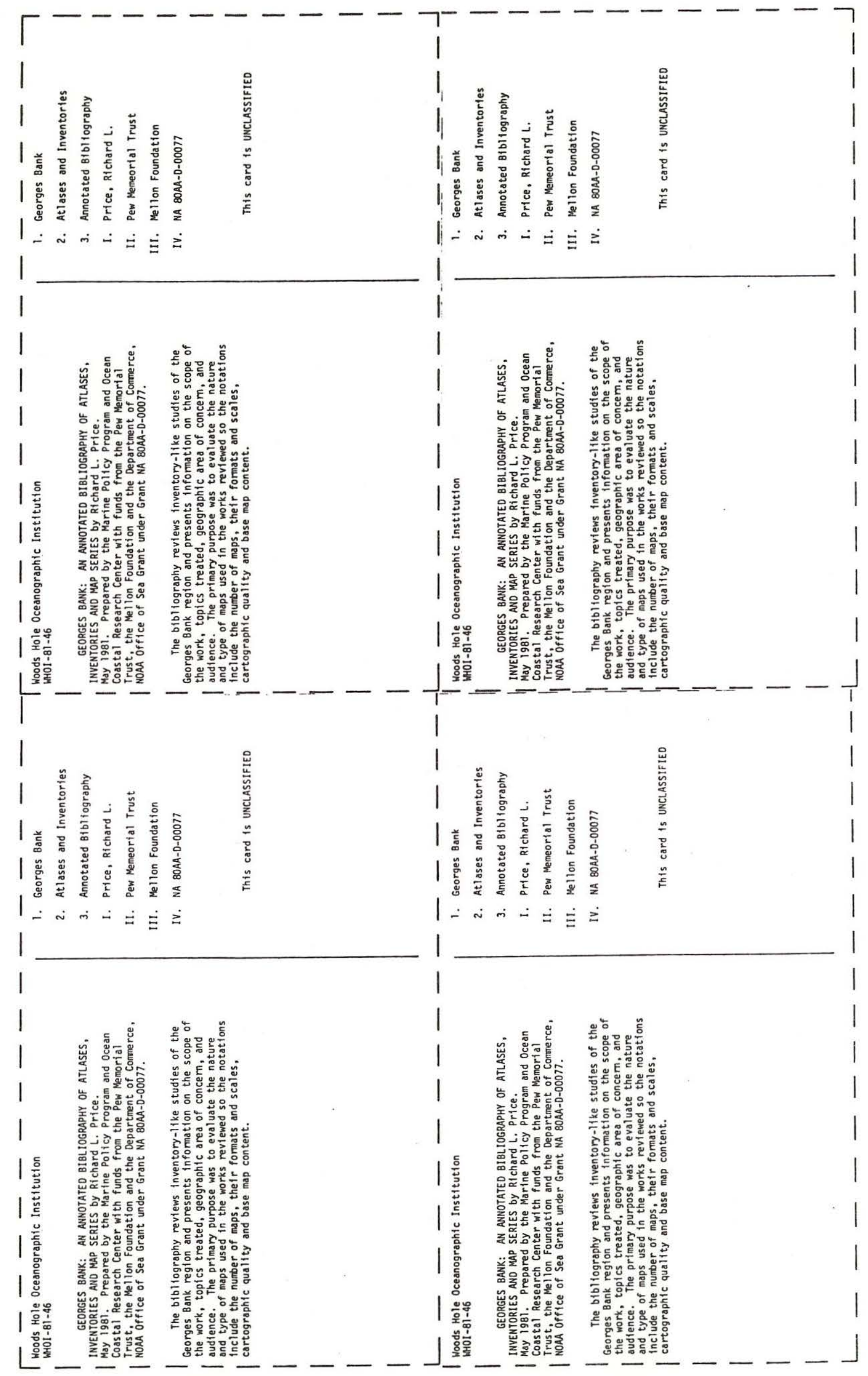

